This item was submitted to Loughborough's Research Repository by the author.

Items in Figshare are protected by copyright, with all rights reserved, unless otherwise indicated.

\title{
Publicity, celebrity, fashion: photographing Edna St. Vincent Millay
}

PLEASE CITE THE PUBLISHED VERSION

http://dx.doi.org/10.1080/00497878.2016.1160750

\section{PUBLISHER}

(c) Taylor \& Francis

\section{VERSION}

AM (Accepted Manuscript)

\section{PUBLISHER STATEMENT}

This work is made available according to the conditions of the Creative Commons Attribution-NonCommercialNoDerivatives 4.0 International (CC BY-NC-ND 4.0) licence. Full details of this licence are available at: https://creativecommons.org/licenses/by-nc-nd/4.0/

\section{LICENCE}

CC BY-NC-ND 4.0

\section{REPOSITORY RECORD}

Parker, Sarah. 2016. "Publicity, Celebrity, Fashion: Photographing Edna St. Vincent Millay”. Loughborough University. https://hdl.handle.net/2134/20835. 


\section{Publicity, Celebrity, Fashion: Photographing Edna St. Vincent Millay}

\section{Introduction}

In her 1936 study Millay and Her Times, Elizabeth Atkins writes of Edna St. Vincent Millay: "Millay represents our time to itself, much as Tennyson represented the period of Victoria to itself, or Byron the period of Romanticism” (vii). As Atkins here acknowledges, Millay was one of the most famous poets of the early twentieth century, if not the most famous. To a considerable degree, this fame was due to the circulation of her photographic image. Millay was not simply a celebrated poet; she was a mass media celebrity, whose image appeared in countless publications, including newspapers, literary journals and magazines such as Vanity Fair, to which she contributed a regular column. She was photographed by the celebrated photographers of her day such as Arnold Genthe, Man Ray, Herman Mishkin, Carl Van Vechten and Berenice Abbot. She was included in the March 1928 Ladies’ Home Journal competition “Can You Name These Modern Poets?” featuring photographs of eleven wellknown poets. Indeed, the relentless mechanical reproduction of Millay’s visual image is implied by Atkins’s words: Millay’s represented the early twentieth century; her image functioned as a mirror for the times, just as Byron and Tennyson's fame is confirmed by the proliferation of their images in nineteenth-century visual culture. ${ }^{1}$

Though falling short of her formidable reputation during her lifetime, scholarly interest in Millay increased in the 1990s, coinciding with the centenary of her birth in $1892 .^{2}$ More recently, Millay has featured in studies of women writers and New York magazine culture (Keyser) and sound recording (Furr), demonstrating that the turn in Millay scholarship is towards cultural studies, productively setting Millay’s popularity in the wider contexts of mass media, material cultures, poetic reception and celebrity studies. But despite 
the plethora of images of Millay, no one has discussed her photographic representations in detail. Photography was key to constructing Millay’s public persona, as Cheryl Walker acknowledges: “Like any good marketing analyst, Millay was canny about packaging [...] both spectacular herself and a manipulator of spectacle” (“Female Body as Icon” 89). However, Walker does not analyse Millay’s photographs or interrogate how this “packaging” was constructed or how it developed throughout Millay’s career.

In this article I focus on photographic representations of Millay, asking what they mean in terms of poetic identity, gender and literary culture. I will discuss these images in roughly chronological order, identifying various personas or phases of Millay. Through looking at Millay in relation to modernist aesthetics, fashion history, the nineteenth-century poetess and in terms of gender and performance, I aim to trace the myriad ways in which Millay used photography to construct a flexible poetic identity. Paying attention to her photographic representations enables us to unpack the mythology of Millay, to trace the construction of an iconic celebrity poet whose self-fashioning and performance style proved influential for later twentieth-century women poets.

\section{Launching Millay}

Millay’s career began with a poem. In 1912, when she was nineteen, Millay entered a poetry competition in The Lyric Year. Her long poem “Renascence” didn’t win, but was included in a published volume with the winning entries. Jessie Rittenhouse, founder and secretary for the Poetry Society of America, wrote in The New York Times: "it seems to me the freshest, most distinctive note in the book" (qtd. in Milford 76). Speculation about the author "E. Vincent Millay” grew. For example, the poet Arthur Ficke wrote to Millay that: “No sweet young thing of twenty ever ended a poem precisely where this one ends: it takes a brawny 
male of forty-five to do that" (qtd. in Milford 79). Millay replied: “I simply will not be a 'brawny male'. Not that I have an aversion to brawny males: au contraire, au contraire. But I cling to my femininity!” (December 5, 1912, Letters 20). She signs off: “P.S. The brawny male sends his picture. I have to laugh”.

This anecdote shows that, even at an early stage in her career, Millay was aware of the complex relationship between her physical appearance, gender and poetic vocation. She is obviously proud to prove she is not a "brawny male" and she uses her photograph to flirtatiously invite further admiration from Ficke. She used a similar tactic to pique the interest of The Lyric Year's editor Ferdinand Earle, sending a playful physical description: "you would perhaps be interested to know that I have red hair, am five feet-four inches in height, and weigh just one hundred pounds," along with a photograph, which he asked to keep (qtd. in Milford 64). At the same time though, Ficke’s assumption that "a sweet young thing of twenty” cannot write powerful poetry suggests that from the very cusp of her career, Millay was going to have to contend with and manage expectations surrounding gender and poetic ability. The association of women with the inspiring muse rather than the active poet was an ongoing challenge faced by women poets - the assumption during the nineteenthcentury being that women "live and inspire [poetry] but they do not write it, while other people - namely, men - have the privilege to do so” (Brown 181). By being photographed, a woman poet risked becoming further enshrined as an object rather than recognised as an active subject in her own right. Nevertheless, a number of canny women poets worked out strategies for negotiating this dilemma by forging a visible professional identity. For example, the fin-de-siècle poet Alice Meynell understood the importance of the "public circulation of a woman poet's visual appearance [...] only distinguished artists or celebrity photographers produced her images, and she suppressed those she disliked or felt unsuitable” (Peterson 177). Like Meynell, Millay realised that her photographic image had the potential 
to entrap her in narrow stereotypes of women's poetry, but it could also be used to her advantage.

Millay’s celebrated poem eventually led her to Vassar in 1913. It was during this time that her most iconic photograph was taken. In the spring of 1914, Millay was invited to visit her publisher Mitchell Kennerley’s country estate at Mamaroneck, New York. Here, she was photographed by Arnold Genthe, who was famous for capturing celebrities such as Isadora Duncan and Greta Garbo, and for documenting the 1906 San Francisco earthquake. Millay was photographed by Genthe standing beneath the blossoms of a magnolia tree, her face averted, her fingers brushing the lower branches [Fig. 1]. This image was the photograph that launched Millay’s career: “[Genthe’s] single shot of her standing among the magnolia blossoms would become the blaze that marked an era in American poetry as her own” (Milford 117).

Genthe’s photograph caught the public imagination not simply because of Millay’s youthful beauty but also because it resonated with some key aesthetic preoccupations of the early-twentieth century, including Orientalism, Paganism and Hellenism. Genthe spent his early career photographing San Francisco’s old China Town, cropping out English language signs and non-Chinese people to make his images look more authentic and "exotic" (Tchen 15). We can see traces of this orientalism in Genthe's photograph of Millay. The delicate blooms and interlaced branches of the magnolia tree resemble the cherry-blossom, an important symbol in Japanese art. Such symbolism links the young Millay to the favoured orientalist trend in modernist poetry at this particular moment. Several early twentiethcentury poets were inspired by the brevity and symbolism of Japanese haiku. In April 1913, Ficke sent Millay Twelve Japanese Painters, his volume of poems inspired by the Ukioy-e school of painters. Ezra Pound composed one of the most famous hokku of all, "In a Station of the Metro” (1913). In 1919, Amy Lowell published her Pictures of the Floating World, 
also inspired by Japanese art. Genthe’s photograph of Millay resonates with such imagery, capturing the mood of Ukioy-e, described by the Buddhist writer Asai Ryōi as "living only for the moment, savouring the moon, the snow, the cherry blossoms, and the maple leaves” (“Tales of the Floating World” qtd. in Hickman 5-6). The delicacy and sorrow of Millay’s photograph conjures this sense of transient beauty.

Genthe's image of Millay also suggests the new freedoms of the female body in the early twentieth century. In keeping with women’s increasing autonomy in the social sphere, fashionable clothing in the late 1910s became looser, inspired by the freedom of movement associated with dancers such as Isadora Duncan, Lois Fuller and Martha Graham. Duncan was a key figure within both modernism and feminism, suggesting new possibilities for the female body:

Duncan's dances were events through which her viewers recognized themselves as modern. They also were shocking, because Duncan performed the female body differently in a period when the transformation of womanhood was both a source of anxiety and a central element of radical theories of liberation. (Francis 25)

In this sense, Duncan’s work in dance resembles Millay’s work in poetry. Millay’s lyrics particularly those published in A Few Figs from Thistles (1920) - equally sought to capture "the new": the fleeting life of the city, of parties, lovers - and these poems shocked too, in their frank expression of subjects previously thought unsuitable for women writers, such as free love, promiscuity, active female sexual desire, and the pleasures of roaming the city. When we compare Genthe’s photograph of Millay to his images of Duncan, we can observe striking parallels in the way they are portrayed. Genthe took hundreds of photographs of Duncan and her troupe from 1915 onwards. In one image, Genthe photographs one of 
Duncan's dancers beneath a tree, her arms raised up towards the branches. This photograph almost exactly replicates his image of Millay [Fig. 2]. The natural setting and the reaching towards the tree branches implies a kind of Pagan nature worship in both images. Such "New Age” ideas were linked by the Greenwich Villagers to free love; embracing nature also meant embracing the body and its pleasures, beyond the cultural strictures placed upon them (such as marriage and monogamy). Such bohemian ideas were expressed through dress: "the body as a shrine and expressing oneself through art, dance, movement, and sensuality facilitated the use of scarves, beads, robes, cropped hair and cosmetics” (Saville 53). Duncan was particularly inspired by Ancient Greek dress. She writes, for example, of a visit to Greece with her brother Raymond: "we had decided that even the Directoire dresses which I wore, and Raymond's knickerbockers, open collars, and flowing ties, were degenerate garments, and we must return to the tunic of the Ancient Greeks” (Duncan 92). In Genthe’s photographs, Duncan wears a draped Greek robe or chiton. Though Millay is dressed more conservatively in her photograph, we can detect a reference to Ancient Greece in her chignon - Duncan herself often wore her hair "rolled and coiled in a loose knot at the nape of her neck” bound with a “fillet” or Greek headband (Duncan 159). In keeping with this, Millay’s poetry often voiced women from Greek history and mythology, such as Sappho and Penelope. $^{3}$

Genthe’s images of Millay and Duncan recall similar photographs of the modernist poet H.D., who was photographed in “Greek” guise. For example, Diana Collecott describes a photograph of H.D. "in Hellenistic profile, with her hair in a chignon, seated in a chair of neoclassical design, recalling classical representations of the muses” (140). Such images confirmed her reputation as the "modern Sappho”. In his review of Heliodora, Louis Untermeyer characterised H.D. as “a wood-nymph lost in modernity, a Greek marble faintly flushed with life, a delightful but detached anachronism” (qtd. in Collecott 104). I propose 
that Genthe is trying to project a similar image of Millay in his portrait by portraying her as an ethereal dryad: "She looked winsome and young and fragile, as if at any minute she might become a wood nymph” (Milford 115). ${ }^{4}$

But although this image promotes the idea that we have just happened upon this nymph-like poetess, Millay was in fact highly conscious of the role she was adopting here. Let us focus on Millay’s outfit in the photograph: a simple, button-down linen smock with a white collar. Millay had recently purchased this outfit at Wanamaker’s department store in New York and was eager to wear it, writing to her family: “I have paid \$10.50 for a tan linen, tailor, cutey, so becoming with a white muslin collar, spring dress, that I really need, to wear to college” (Spring 1914, qtd. in Milford 115). The tone here is playful, as Millay’s letters tend to be, but it is significant that she purchases this dress knowing how "cutey" she will look in it. The emphasised "so becoming” reads like the rhetoric of a fashion magazine which is where Millay's image would be reproduced, in the pages of Vanity Fair. ${ }^{5}$ The illusion of artlessness cultivated by the dress is therefore complicated by the ironic selfawareness conveyed in Millay’s letter. Youthful, minimalist, “cute,” this outfit is nonetheless a carefully planned costume chosen by Millay for her first publicity photograph. Shrewder than she looks, Millay knows there are benefits to playing the ingénue.

This self-awareness is clear to see in Millay’s later writings for Vanity Fair. From 1919 onwards, Millay began writing short pieces under the pseudonym of “Nancy Boyd”. Millay’s Boyd pieces often take a satirical look at the events and images that shaped her own career. For example, in one Boyd piece, Millay writes:

Why is it that the girls of so many of our best families, the hope of our land, as you might say, insist upon getting all safety-pinned up into several yards of mosquito- 
netting and standing about somebody's golf-links while Arnold Genthe takes their photograph? (“The Greek Dance: — A Chorus of Hate” 47)

Here, Millay sends up her own by-then iconic photograph, turning Kennerley’s estate into "somebody’s golf-links" and referencing her ethereal pose as unpoetically "standing about". The mosquito-netting is an interesting detail, as Millay did in fact wear mosquito-netting as a veil when marrying Eugen Boissevain in July 1923 [Fig. 3]. Millay was clearly aware that the artifices employed to create the appearance of ethereality (necessary to the poetess image demanded by the public) were often absurd in reality. Elsewhere, Millay includes a portrait of herself, spied by Boyd in the act of "eating an enormous plate of sauerkraut and sausages," which Boyd declares was "a shock. I had always imagined her so ethereal” ("Diary of an American Art Student” 44). Here Millay delights in deflating mythologies surrounding the disembodied, delicate woman poet, indulging in an ironic parody of her own celebrity persona.

Millay's self-awareness to the point of self-dissection is also apparent in her unpublished self-portrait poem written in the spring of 1920. Millay and her friends John Peale Bishop and Edmund Wilson challenged each other one evening to compose selfportraits. Millay’s poem is incredibly revealing of her attitude towards her physical appearance:

Hair which she still devoutly trusts is red.

Colorless eyes, employing

A childish wonder

To which they have no statistic

Title. 
A large mouth,

Lascivious,

Aceticized by blasphemies.

A long throat,

Which will someday

Be strangled.

Thin arms,

In the summer-time leopard

With freckles.

A small body,

Unexclamatory,

But which,

Were it the fashion to wear no clothes,

Would be as well-dressed

As any. (qtd. in Letters 99-100)

Whilst this description asserts a quiet confidence in the value of this "small body," there are darker undertones to the description. As Walker notes, the reference to strangling hints at violence directed towards the female body and there is something disturbingly “clinical about Millay’s description, as though her body were part of a department store inventory” (Masks Outrageous 139). The itemising blazon contributes to this sense, as it moves downwards listing hair, eyes, and mouth in a slender line on the page, as if Millay had chopped herself into pieces and offered them up to the reader's gaze. As Stacy Carson Hubbard observes, the blazon, derived from medieval troubadour poetry "identifies the poet-lover both with the potential buyer and with the merchant who displays the woman's wares” (104). In the case of 
Millay’s sexually-liberated poetry, Hubbard notes "women [...] aim to do their own spending” (104). This may be true, but in order to enter the erotic economy at all, Millay’s poetry suggests that women will have to learn how to sell themselves, composing the blazon that puts their body on the market.

Being photographed directly contributed to Millay’s sense of being “on the market”. Cucinella notes that Millay's self-portrait poem echoes a letter to her family, written after being photographed by Genthe: “Besides having beautiful hair, an extraordinary good forehead in spite of the freckles, an impudent, aggressive, \& critical nose, and a mysterious mouth, I have artistically, \& even technically, an unusually beautiful throat” (September 17, 1914, qtd. in Milford 117). ${ }^{6}$ Here Millay views herself with detachment: she notes her "flaws" (“in spite of freckles”), assigns characteristics to her features and adopts a criteria (presumably derived from Genthe) that defines her throat as both "artistically” and “technically" beautiful. The vulnerability of the throat, on which Genthe chose to focus on this occasion - Millay writes Genthe “made me lean forward \& lift back my head, - and photographed my throat!” (qtd. in Milford 117-118) - recalls her suggestion that she might be “strangled”. In this instance, Millay’s throat is quite literally Genthe’s "target”, the point of focus that his camera seeks to capture. Lindsay Smith links focus to the Freudian concept of the fetish: "Focus as photographic state may thus in a sense be read as fetishized with its antithesis 'out of focus' thereby becoming commensurate with a fear of castration” (30). Millay’s long throat, draped “in a heavy deep-blue velvet cloak to reveal it” (Milford 117) here becomes the focus of Genthe’s fetishistic gaze.

As her self-descriptions suggest, Millay was enthusiastically complicit in marketing her various parts. Her sense of being a product for sale was further intensified by the location of her work and image in fashion magazines such as Vanity Fair. We can therefore see how Millay became adept at viewing herself as a product, assessing her various selling-points and 
emphasising them in her photographic representations. In this sense, she is an ideal figure for demonstrating the art critic John Berger's assertion that:

Women watch themselves being looked at. This determines not only most relations between men and women but also the relation of women to themselves. The surveyor of woman in herself is male: the surveyed female. Thus she turns herself into an object - and most particularly an object of vision: a sight. (47)

From her early experience of the sensation surrounding the Genthe photograph, Millay learnt to commodify her image, becoming an expert at turning herself into “a sight”. As her celebrity grew, mostly thanks to the promotional efforts of Vanity Fair from 1920 onwards, she became increasingly conscious of the role her photographic image played in promoting her poetry, and she adapted that image according to the demands of the changing market.

\section{Millay’s “Charmed Mantles”: Clothing the Poetess of Greenwich Village}

I now want to move onto a crucial aspect of Millay’s visual appearance: what Millay wore. As the “it girl” of 1920s America, Millay’s sartorial choices embodied Greenwich Village bohemianism. With her bobbed hair and penchant for loose-flowing robes, especially kimonos, Millay’s appearance was characteristic of the Village, where dress served to signify an individual's political and ideological allegiances. As the fashion historian Deborah Saville observes: "Villagers distinguished between reform dress and artistic dress; the latter included long robes of silk and Chinese sandals” (41). Reform dress was characterised by items such as billowing “Russian blouses,” sack-like “artist’s smocks” and chunky sandals (Saville 39). Such clothing was associated with the radical politics of its wearers, such as the socialist and 
feminist Henrietta Rodman, who advocated free love and birth control. Artistic dress was more elaborate and decorative; clothing was flowing and draped, inspired by classical styles (such as the chiton or toga), and adorned with embroidery, smocking, and batik - a Javanese method of dying fabric with wax, available at Manhattan markets by 1912 (Saville 43).

Millay was more aligned with artistic dress than reform dress. Although she was politically active (advocating suffrage, supporting Sacco and Vanzetti in 1927 and vocally opposing fascism in the 1940s), she may have been cautious that, as a poet, her appearance should be ethereal and artistic rather than overtly radical and challenging. However, Millay’s bobbed hair (she had it cut in 1920, describing it as “'Sawful cute,” Letters 101) certainly marked her out as a New Woman and signified her freedom from convention, associating her with the female flapper image that took hold in the 1920s. Millay owned dresses by the designers Paul Poiret and Mariano Fortuny, both of whom were popular designers for the New York avant garde: “I appeared in my most beautiful evening gown, - a Poiret gown, by the way, which I bought at a place where they sell the gowns which have been worn by the models” (Millay to Norma Millay, July 24, 1921, Letters 122). Breaking away from the corseted, restrictive designs of the late-nineteenth century, these designers took inspiration from antique and Eastern designs, with an emphasis on drapery, freedom of movement and wide, kimono-inspired shapes. Millay was exceedingly fond of kimonos and sought authentic kimonos to add to her collection. For example, in October 1920, Millay requests that her friend Witter Bynner, who was going travelling: "bring me a whatever is the Chinese equivalent for kimono [...] And you mustn’t neglect it till you get back here, and then try to fool me with some batiked dish-towelling from Vantine's” (October 29, 1920, Letters 104). Vantine’s was a shop in New York selling imported Oriental goods. Their 1919 catalogue advertises “[d]ainty boudoir garments that are practical and pretty,” assuring the reader that “Vantine’s kimonos are typically Japanese” (Vantine 58-59). Prices range from \$8.50 to 
\$22.50. Millay’s letter suggests that although her tastes were very much in line with Greenwich Village fashion crazes, she sought to distinguish herself from the crowd by the authenticity and quality of her garments. We can observe these oriental influences when looking at Millay's dress and shoes in the National Museum of American History. ${ }^{7}$ The dress is a rose-pink kaftan with long, draped sleeves and a wide neck, edged with gold embroidery. The shoes are pointed Indian slippers. The intricate beading on the slippers and the embroidery on the silk kaftan verify Millay’s commitment to artistic dress.

As early as 1917, Millay realised the impact clothing could have on her audience. She writes to her family of a reading for the wealthy Mrs Hooker and her guests:

My trunk hadn’t come \& so she dressed me up in something of hers, a gown with a train \& hanging about six inches on the floor all around, made out of three rainbow colored scarfs. And, family, I discover that I have nothing to give readings in, I must have long dresses, trailing ones. The short ones won’t do. If Norma hasn’t yet done anything to the greenish chiffon \& rose scarf then that dress ought to be made up very long \& drapy - more like a negligée than a dress, really - very graceful \& floaty. (September 27, 1917, Letters 76)

As Millay’s biographer Daniel Mark Epstein notes, these “negligees with their long trains became her “charmed mantles” (119). The impact of Millay’s dramatic dress is described in accounts of the live readings that she gave throughout her career. For example, a report of her 1925 reading at Bowdoin College, Maine states that she wore:

a robe of gold and bronze and green and her voice was a bronze bell as she read. Back and forth she moved, by turn grave and gay, pompous and flippant. Her robe, because 
it was traced with gold threads woven into its pattern, whispered and chimed faintly against the floor. If Miss Millay had not been a poet she could easily have been an actress. (“Edna St. Vincent Millay Reads Her Poems at Literary Institute”, n.p.)

Of the same event, the Boston Sunday Globe reported: "She wore a loose flowing gown of gold and bronze without a semblance of a girdle. Her sleeves, bound at the wrist no larger than a ring, flared above the elbow. But what is the use of trying to describe the way her gown fell to the top of her gold slippers and her trick of flicking the train in back of her?” (Hurd Jr. 12). As these accounts suggest, on stage, Millay conveyed the image of the poetess chiefly through her wardrobe of dramatic costumes. Derek Furr notes that Millay was billed as "poetess” whereas Willa Cather (the only other woman writer on the Bowdoin programme) was listed as “novelist, author” (99). Millay’s billing raised certain expectations in her audience: a "poetess" was expected to be delicate, enchanting and above all, feminine, continuing the tradition of popular nineteenth-century women poets such as Letitia Elizabeth Landon (L.E.L.) and Frances Sargent Osgood, who were associated with domesticity, sentimentality and effusion.

Through her dramatic costumes and theatrical use of her body and voice, Millay sought to literally embody the poetess in her live performances. This led her body to be collapsed with her work: one reviewer stated that: “Millay’s poems are as well-turned as her own slim ankle” (qtd. in Cucinella 28). Another compared Millay’s poetic skill to her fashion sense, stating that in both she was apt to be "careless":

[Millay] is like a beautiful woman who was a varied, attractive wardrobe, and if one may judge from some of her appearances, she knows how to wear her clothes: but she 
does not always take the trouble to select discriminatingly or to put them on properly, or at least as effectively as she might do. (Collins 118-119)

Just as Millay’s work was associated with her physical appearance, her poems were often interpreted as personal revelations. In this sense, Millay elicited a similar response to earlier, nineteenth-century poetesses such as Osgood, L.E.L. and Felicia Hemans, whose poetry was understood as providing “imaginary public access to a poet’s idealized interior, and therefore to her presumably inviolable soul or spirit,” offering "a glimpse inside herself that was often perceived as erotic” (Zellinger 243-4). As several critics have shown, in the eighteenth and nineteenth centuries we can trace a distinctive tradition of the poetess, founded on the idea of women’s poetry as effusive “self-expression”- a spontaneous overflow of feeling expressed via the lyric. ${ }^{8}$ This tradition takes its inspiration from the Ancient Greek poetess Sappho, the "first" woman poet, who eventually committed suicide due to unrequited love for the fisherman Phaon. This image of the dramatic “improvisatrice” is developed in Madame de Stael’s Corinne (1807), which imagines the woman poet as a captivating performer. L.E.L. and Hemans continued this theme in "The Improvisatrice" (1824) and "Corinne at the Capitol” (1830).

This imitation of Sappho went beyond poetry into the realms of self-fashioning. For example, Emma Mason observes that L.E.L. "took to publicly dressing as the improvisatrice in a flamboyantly Sapphic costume” (7). Hemans was also aware of the pressure to play up to the poetess image, writing: "If I were in higher spirits, I should be very strongly tempted to do something very strange amongst them, in order to fulfil the ideas I imagine they entertain of that altogether foreign monster, a Poetess” (qtd. in Mason 7). Hemans’s wry comments anticipate Millay’s jest about the need to wrap oneself in "mosquito netting” in order to fulfil what is expected of the unconventional poetess. Like Hemans, Millay chafed under the 
pressure of her own popularity, complaining of feeling "like a prostitute” at one heavilyattended private reading (January 1924, Letters 181). This sense of sexualised self-exposure can be traced in the work of many nineteenth-century women writers, who often conceptualised literary fame as a dangerous denudation before the public gaze.

Evidence suggests that Millay was familiar with the work of nineteenth-century women poets. At Vassar, she took courses in "Nineteenth Century Poetry, and Later Victorian Poetry” (Letters 48). Millay’s mother encouraged her daughter to read nineteenthcentury poetesses such as Hemans and Jean Ingelow and also "published her own feminine, sentimental, didactic poetry in northeasten newspapers beginning in the 1890s” (Zellinger 249). It should not, therefore, surprise us that elements of the poetess tradition influenced Millay’s performance style, in which she played the modern Sappho, wearing robes that trailed musically in her wake. Like L.E.L.'s improvisatrice, Millay projected a sense of spontaneity in her performances, in spite of her carefully planned set-list: "[Millay] enjoyed chatting with the audience between poems; her program, however, would always follow a strict schedule, which would skilfully create the impression of spontaneity and improvisation” (Michailidou 125). It is also worth remembering that Millay was an actress as well as a poet - she had worked with the Provincetown Players and performed in plays while at Vassar. Taking inspiration from the theatre, clothes for Millay were really more akin to costume. We can see this in the reviews of her live readings, which refer to the dramatic "sweep" of her robe on the floor and the "trick" of flicking her train behind her. Millay's clothes were a crucial aspect of her performance, creating a distance from the everyday self and projecting an image of the iconic poetess guaranteed to hold her audience spellbound. Sandra Gilbert and Susan Gubar argue that Millay was in this sense a "femalefemale impersonator": although conscious of femininity as a masquerade, she nonetheless manipulated its conventions in order to forge a public poetic identity. Through her 
performance of hyperfemininity, Millay simultaneously draws on and interrogates the tradition of the nineteenth-century poetess. In her live performances, Millay dramatises the poetess's authenticity, rendering it theatrical, illustrating "the emptiness of personal expression in a genre that staked itself on being a public presentation of the private” (Zellinger 243). Millay’s choice of clothing was crucial to this demonstration - her "charmed mantles” cultivate the aura of the poetess, while simultaneously revealing that identity to be a performance.

\section{Suit and Tie: Millay in the 1930s}

In their emphasis on Millay as “female female” impersonator, Gilbert and Gubar overlook a significant facet of Millay’s self-presentation: she also played with masculinity. For example, in 1915, while at Vassar, Millay played the role of the young poet Marchbanks in George Bernard Shaw's Candida [Fig. 4]. She wrote to her family: "I felt perfectly at home in the clothes. People told me I reminded them of their brothers the way I walked around and slung my legs over the arms of chairs, etc ... Somebody thought I was really a boy” (qtd. in Epstein 92). In the final section of this article, I will explore the construction of female masculinity in Millay’s later photographic images, proposing that Millay’s androgynous persona has been overlooked by biographers and critics, because it undermines the image of the feminine ingénue which launched Millay’s career. ${ }^{9}$

As mentioned above, Millay clearly enjoyed dressing up, viewing clothes as theatrical playthings that enabled her adopt various identities. However, although these roles were often markedly feminine - "femme fatale [...] cheerful flapper and a weary princess” (Gilbert and Gubar 76) - Millay also experimented with more masculine personas. For example, during a trip to Albania in 1921, Millay was photographed in traditional Albanian dress [Fig. 5]. This 
image is strikingly similar to the portrait of Lord Byron in Albanian Dress by Thomas Phillips (1835). Millay was often compared to Byron - for example, in a 1931 magazine piece, Elizabeth Breuer writes: “we have to go all the way back to Byron to find one who has been, like her, so much a matter of personal excitement to her generation. Like Byron, she speaks for the young, the rebellious” (2). Despite their obvious differences, Millay and Byron share some similarities, such as a high level of celebrity and scandalous love life that fascinated the press of their day. They were also not averse to co-opting “exotic" cultural identities in order to increase their mystique, as proved by their adoption of Albanian costume. In donning Byron’s Albanian dress, Millay adopts two layers of “otherness,” playing with both gender and ethnicity.

Millay was not the first woman writer to identify with Byron. Andrew Elfenbein observes that nineteenth-century women writers such as Hemans, Caroline Lamb, Mary Shelley, and Charlotte Bronte adopted the Byronic hero "as a figure for themselves as authors” (65). Such an identification is aided by gender-crossings in Byron’s work, such as the Turkish episode in Don Juan (in which Juan becomes “Juanna”) and by Byron’s own gender ambiguity: he was described by Isaac Disraeli as "a fantastic and effeminate thing [...] more like a girl than a boy” (qtd. in Elfenbein 209). The precise nature of Byron's sexuality remained under scrutiny; the breakdown of his marriage led to hints of incest and sodomy. By adopting Byronic costume, Millay signals her affinities with this sexual outlaw, whose celebrity and rumoured bisexuality echoed her own risqué public image.

Millay continued to play with masculine identities in her photographs of the 1930s. In portraits by Berenice Abbott (1929 and 1940), Herman Mishkin (1930) and Carl Van Vechten (1933), Millay wears a smart suit jacket, shirt and tie. Her hair is cropped and - in Mishkin's portrait - she appears strikingly androgynous, the large ring on her finger the only feminine adornment [Fig. 6]. Millay was not alone in experimenting with female masculinity 
during the 1920s and 1930s. Abbott's photographs chronicle the expatriate community of female artists, writers, and journalists in Paris who dressed in starkly masculine fashions and wore their hair short (Jane Heap, Thelma Wood, Janet Flanner, Sylvia Beach and Princess Eugène Murat). As Gaëlle Morel observes, these “female subjects express a 'sexual ambiguity,' as evidenced by their haircuts and masculine dress as well as their suggestive poses, which deliberately convey a sense of uncertainty surrounding their sexual identity” (13). The style and bearing of these women is simultaneously an expression of artistic freedom, a hallmark of modernity, and a signifier of lesbian/bisexual identity. As Terri Weismann notes, these sitters are "framed by [their] own terms of definition," taking control of the camera's gaze (53). In Murat's portrait, for example, her “frankly confessional stare” at the viewer "issues her a kind of autonomy [...] she cannot be contained" (Weismann 68). It is worth noting that Abbott's images arose naturally from her sitters: they wore their own clothes and were not posed by the photographer.

Abbott photographed Millay on at least three different occasions: 1929, 1931 and 1940. Abbott proposed the first photoshoot, writing to Millay when she was considering returning to New York and setting up a photographic studio there:

Dear Edna, I have just seen Margot Schuyler and in the course of our conversation, we were discussing yourself, herself, myself, photography et cetera which brings me to the point of such a proposition. I hope you remember me from the hectic days of New York and Paris - and at least a few beautiful dances we have had together. (Abbott to Millay, February 11, 1929)

Abbott here builds on a network of lesbian attachments (Schuyler was one of Millay's lovers) in order to gain a prominent client. This letter is flirtatious; reminding Millay of their 
"beautiful dances" in order to arouse her interest. Paris was well-known as a venue for exploring same-sex desire, and Millay participated in that world, befriending the poet and society hostess Natalie Barney and the painter Romaine Brooks. Like Abbott's photographs, Brooks's portraits chronicle the lesbian world of Paris in the 1920s, portraying women who exhibit strikingly masculine fashions.

Millay accepted Abbott’s proposal and a number of portraits were taken. One shows Millay in a dark, beaded evening gown, slashed at the neck and sleeves (the same gown she wore for her wedding in 1923, most likely designed by Poiret or Fortuny). ${ }^{10}$ She leans forward, exposing her much-admired throat, her expression pensive. Around her neck she wears a distinctive tear-drop pendent which (as the newspapers confirm) was given to her by her friend the poet Elinor Wylie, who had died in 1928. This image was used almost exclusively to publicise Millay’s Fatal Interview in 1931, a volume of love sonnets inspired by her affair with a young poet, George Dillon. Several newspapers highlight the Abbott photograph as a new image of Millay - as if this were as much of an event as the new volume of poems - and note the connection to Wylie. For example, the Chicago Evening Paper remarks: 'Miss Millay is seen wearing the necklace given to her by the late Elinor Wylie, to whom this book is dedicated’ (10 April 1931), printing Millay’s poetic dedication alongside the photograph. This portrait therefore constructs Millay as both an elegant and an elegiac poet, dressed in evening wear and jewellery which indicate her indebtedness to another woman poet. This focus on female friendship and loss subtly draws attention away from the risqué eroticism of the love sonnets, addressed to a man other than Millay’s husband.

Other Abbott portraits show a remarkably different Millay. In another photograph, taken in 1931, she wears a grey skirt-suit and tie, with a sharp white collar. Millay gazes out at the viewer, her pose fairly relaxed as she rests her (ringed) hand on the back of the chair and tilts her head. ${ }^{11}$ The image suggests an uneasy attempt at intimacy - Millay’s direct gaze 
displays a genuine desire to connect with Abbott/the viewer, but reserve is implied by her strained expression. In another "suit and tie” image from around 1930, Millay appears more nervous, looking away from the camera. ${ }^{12}$ Her hands are crossed over her lap; the black background merges with her suit, highlighting her white collar and cuffs. She manages to look both remarkably childlike and rather worn. Taken as a group, Abbott's photographs of Millay intriguingly combine elements of femininity and masculinity, intimacy and reserve, youth and age. The soft focus on Millay's waved hair and ringed hand, and her crossed legs and knee-length skirt emphasise her femininity and modesty, but her sharp collar and striped tie in both images project a business-like masculinity.

Millay’s white collar and dark suits bring us back to Byron, who famously wore “dark clothes set off by white linen at the neck and wrists" (Kenyon Jones, "Fantasy and Transfiguration” 113). Byron’s appearance sparked a fashion craze, and his look was adopted even by female admirers; an 1835 portrait believed to be Felicia Hemans depicts her with a large white collar [Fig. 7]. This image bears striking similarities with Abbott's portraits of Millay. Although I am not suggesting that Millay consciously based her appearance on either Byron or Hemans, I am suggesting that Millay increasingly recognised the power of sartorial choices that were androgynous, unfussy (suggesting the poet meant business), and had historical resonances with previous manifestations of poetic genius. Even Millay’s 1933 portrait by Carl Van Vechten with loosely open blouse and dark suit jacket recalls Byron’s "poet's uniform, with the dark clothes and open shirt collar" (Kenyon Jones, "Byron’s Body" 100).

In addition to their nineteenth-century resonances, Millay’s fashion choices were also very much of their own historical moment. "Masculine” dress was very fashionable in the 1920s. For example, in 1924, the Daily Express praised the “ultra-masculine” cut of the latest tailor-made suits for women and "the mannish high white collar of stiff but exquisitely fine 
white linen” (qtd. in Doan 116-117). This vogue for masculinity enabled figures such as Radclyffe Hall and Una Troubridge to express gender ambiguity and lesbian identity, whilst also being “the height of fashion” (Doan 117). A similar dual-meaning permeates Millay’s suit and tie portraits. On one level, Millay’s tailored clothing is simply chic. However, her well-documented bisexuality lends a further significance to this androgynous portrayal. Millay had relationships with several girls at Vassar and she continued to have female lovers, including the actress Edith Wynne Matthison and Margot Schuyler.

In this sense, Millay’s masculine persona - signified by her nickname “Vincent” and embodied in her androgynous photographs of the 1930s - can be read as a covert yet knowing expression of her sexuality. As Nicky Hallett notes (in her discussion of Romaine Brooks’s paintings) the adoption of masculine styles by lesbian/bisexual women need not play into pejorative stereotypes of gender inversion, but may instead reflect a playful, self-aware and critical engagement with such stereotypes:

[Brooks] portrays the lesbian use of the cliché, so the fact that lesbians often did choose such sartorial style [...] is itself part of the subject, and the artistic play with ideas of self-realisation [...] the lesbian subject is already part of her own selfreference [...] as an agent, she has already engaged with dominant modes of selfexpression, and has chosen to appropriate them, subvert or ignore them. (183) ${ }^{13}$

We can reinterpret Abbott's photographs of Millay in light of these observations. These images set up a scenario whereby the sitter (Millay) and the photographer (Abbott) participate in playing with signifiers of lesbian identity. The timing of these photographs is significant. Following The Well of Loneliness obscenity trial in 1928, masculine fashions for women "came to be linked unequivocally with sexual abnormality" (Doan 192). Thus, Millay 
boldly and deliberately adopts masculine dress at precisely the historical moment when such sartorial style becomes loaded with contentious meanings.

But despite the prevalence of these images, Millay’s androgynous persona is often overlooked. It is played down by her interviewers in the 1930s, who still portray Millay as a fragile young thing. For instance, after comparing Millay to Byron in her opening paragraph, Elizabeth Breuer describes Millay as "a little figure with a delicate face and red-gold, curly hair, dressed in white” (2). Breuer might wish to play down Millay’s androgyny because it was potentially threatening - especially when combined with her childless status, her open marriage, and her formidable career success. Age is also a factor here: in contrast to the boyish Modern Girl, the masculine woman was more threatening: “The Masculine Woman, older in age than the Modern Girl, seemed ominously poised to disturb sexuality as well as gender” (Doan 106). Nearing forty, Millay could no longer be categorised as a modern "girl” simply playing with boyishness. Her masculinity had more troubling implications.

The downplaying of Millay's female masculinity is not confined to the early twentieth century. Millay’s 2001 biographer Daniel Mark Epstein finds Millay’s 1930s photographs threatening, to the point of dismissing them entirely:

There are hundreds of photographs of Millay. The most widely known and reprinted are the most misleading [...] from the severe Mishkin portraits of the twenties [sic] where Vincent in pageboy, gentleman’s coat, and necktie looks like Rupert Brooke needing a haircut [...] This is not, nor was it ever, Edna St. Vincent Millay. (135)

Epstein goes on to speculate that Millay chose to be portrayed as "a nun, a librarian, or a lady lawyer” (135) because she didn’t want to run the risk of appearing too alluring in public, and thus having her public persona associated with her sexually adventurous personal life. But 
this contradicts Millay's other publicity strategies: as we have seen, sensual femininity was something she projected in other press photographs and emphasised in her live performances. Epstein concludes that Millay would not have written her celebrated sonnets if she had not been so attractive: "If she had looked like Edith Sitwell, Edith Wharton, or any other Edith; if she had resembled Amy Lowell or Emily Dickinson; if she had not had the effect on men that she had [...] she would not have written the sonnets that are now under discussion” (Epstein 135). The fact that such opinions are published in 2001 underlines the enduringly uncomfortable relationship between appearance, photographic representation, and female poetic identity. Physical appearances, enshrined in photography, may indeed be proven to have had a largely unacknowledged influence on the reception of women poets. For example, Adrienne Munich and Melissa Bradshaw suggest that Amy Lowell's waning critical fortunes may in part be attributed to the fact she was fat (xxiii). A glamorous image may help a woman poet survive into posterity, while less appealing images are suppressed as not "true" to this idealisation. In this context, photographic images become a battleground of interpretation. Epstein’s disavowal of Millay’s androgynous persona reads like an anxious attempt to ward off queer interpretations of her life and work; to enshrine her as the sexy muse of a series of male admirers.

The problematic nature of Epstein’s comments aside, his observations are at least correct in one sense. He is right that, along with Genthe’s portrait, the androgynous photographs of Millay are among the most frequently reproduced, even if biographers and critics are curiously silent about them. ${ }^{14}$ A disjunction opens up then - between the ethereal girl-poet portrayed by Genthe, Millay’s floaty persona at her dramatic public readings, and the austerity of her dress and bearing in these later photographic images. Why did Millay play the poetess in performance and the androgynous poet in her late photographs? Was she 
expecting and negotiating a different audience for these images than for her public readings? Or was this simply a new "phase” of Millay?

We can perhaps view Millay’s business-like look as a way of negotiating aging. By the 1930s, Millay knew she could no longer play the ingénue, and projected a more professional image. Walker recognises that aging proved a challenge for Millay, comparing her to Madonna in her insistence "that her body was somehow independent from the frames in which others sought to bind its significance” ("Female Body as Icon” 90). She concludes that Millay’s strategies were ultimately unsuccessful, citing Jean Starr Untermeyer’s unflattering description of Millay in 1942:

Her hair, which she wore in a long pageboy cut, was now shades lighter than the redgold locks of her girlhood [...] the face under that thatch of yellow hair had changed almost unbelievably: it had aged but not ripened. With its flushed cheeks it reminded me of a wizened apple. (qtd. in Walker, “Female Body as Icon” 90)

Walker argues that Untermeyer's description recalls the narrative of the aging starlet whose body "eventually becomes the rejected toy of her audience” (90). In a desperate attempt to regain her former glory, the aged star apes her own youth, with grotesque and tragic results. Walker suggests that Millay’s career illustrates that “constant rewinding ultimately erodes the glamorous celluloid image” (90). In other words, her attempts to prolong her girlhood only serve to undermine her former glamour and hasten her inevitable decline.

However, I think Walker’s reading is too simplistic, particularly given Millay’s career success continued late in life (for example, her 1939 volume Huntsman, What Quarry sold sixty-thousand copies within one month). She was still heavily photographed, taking part in a photo-shoot for Town and Country magazine in the 1940s. I therefore want to propose an 
alternative to this narrative of the waning star: that Millay was in fact actively playing with her image to the last, rather than constantly "rewinding” to her girlhood. In this sense, she can indeed be compared to Madonna, but in terms of her amazing capacity for reinvention. In this article, we have seen Millay transform from ethereal ingénue, to Bohemian flapper, to inspired improvisatrice into the androgynous poet-businesswoman of the 1930s. In the 1940s, Millay becomes the sage-like grand dame, reflecting her confirmed status as one of the most successful poets of the age. Consider, for example, Alfred Eisenstaedt's 1941 portrait. ${ }^{15}$ A mature Millay gazes confidently at the camera, a knowing humour in her eyes and a smile playing on her lips. She looks witch-like and stately in her dark suit, and - unlike in Genthe’s image, where she turns away from the camera, or the uneasy intimacy of Abbott's portraits she looks relaxed and self-assured. This image does not speak of the "fading star" but the confirmed doyenne of the poetry scene.

Another fascinating image of Millay arose from the 1942 photo-shoot by New York’s National Broadcasting Company, which was arranged to promote her dramatic poem "The Murder of Lidice”. The photograph shows Millay stood in front of a painting of a rather sardonic clown [Fig. 8]. This painting, a Pierrot by Walt Kuhn, was purchased by Millay in 1938: "I have bought a painting by Walt Kuhn, one of the clown ones, a beauty, the terms being one million dollars down and a ball and chain around my ankle for the rest of my life" (Letter to George Dillon, December 29, 1938, Letters 304). Though Millay complains about the cost, this painting was clearly a symbol of her wealth and status as this point in her career - of the fact she had one million dollars to spend on art (she had recently completed another successful reading tour). The prominence of the painting in this promotional photograph suggests she was happy to show off this expensive purchase.

But beyond being a symbol of Millay’s success, I want to suggest that this painting provides an apt image for Millay herself, who stands in the foreground looking comically 
stern and flicking through a sheaf of her poems. The clown looks out at us, the viewer, with painted face and silly hat, but weary eyes. This is the position of Millay herself vis-à-vis the photographic image - ready to play, to put on the mask and the make-up, but never quite falling for the artificial identities she adopts. Instead, Millay viewed such identities with an ironic detachment that enabled her to constantly reinvent her image. Her lifelong identification with the clown is signified by her adoption of the Pierrot figure in works such as Aria da Capo, and further underscored by her choice of fancy dress at the Illustrator's Ball [Fig. 9].

Millay was a chameleon, who used her image flexibly throughout her career to play on (and to subtly subvert) the expectations surrounding the poetess. She did this not only through her poetry and writings, but also through her photographic images, her dress and her public performances. In doing so, Millay took active part in reinventing female poetic identity and its manifestations in the twentieth century. Her strategies were influential for later poets in the twentieth century, such as Anne Sexton, who was inspired by “Millay’s conscious and often provocative presentation of herself as both object and controller of desire” (Michailidou 126). Millay became an object through posing for the camera, but she controlled that performance from beyond the frame, playing with her identity to the last.

\section{Notes}

${ }^{1}$ See Christine Kenyon-Jones (2008) and Jim Cheshire (2009).

${ }^{2}$ Among the most significant publications are Suzanne Clark’s Sentimental Modernism: Women Writers and the Revolution of the Word (1991); two biographies (by Nancy Milford and Daniel Mark Epstein, both 1991); two essay collections, Critical Essays on Edna St. Vincent Millay (Ed. William B. Thesing, 1993) and Millay at 100: A Critical Reappraisal (Ed. Dianne P. Freedman, 1995) and Nina Miller’s Making Love Modern: The Intimate 
Public Worlds of New York’s Literary Women (1999). Sandra Gilbert and Susan Gubar (1994) and Cheryl Walker (1991) also devoted chapters to Millay.

${ }^{3}$ For example, 'Sappho Crosses the Dark River into Hades’ (Wine from These Grapes, 1934) and 'An Ancient Gesture' (Mine the Harvest, 1954).

${ }^{4}$ Ezra Pound called H.D. 'Dryad' in his earliest poems in 'Hilda’s Book' (1905-7).

${ }^{5}$ The earliest image of Millay in Vanity Fair is a portrait by Marcia Stein which accompanies an article on American dramatists (August 1920). In November 1920, Vanity Fair features a whole page of Millay poems, again accompanied by a Stein portrait. Stein was the sister of Herman Mishkin, whose photographs of Millay in the late 1920s are among the most frequently reproduced. One of the earliest instances of the Genthe portrait is in the New York Evening Post, July 16, 1921, accompanying a review of Millay’s Second April.

${ }^{6}$ Sadly the photographs from this session with Genthe are lost (Epstein 91).

${ }^{7}$ Images of Millay's dress and shoes can be found on the National Museum of American History, Smithsonian Institution Flickr page at: <https://www.flickr.com/photos/nationalmuseumofamericanhistory/sets/72157633318019203 >

${ }^{8}$ See Armstrong (1993), Yopie Prins (1999) and Margaret Reynolds (1996).

${ }^{9}$ I borrow the term “female masculinity” from Halberstam (1998).

${ }^{10}$ This image can be found on the Beinecke website at:

< http://brbl-dl.library.yale.edu/vufind/Record/3776576> and also at:

< http://www.queerblog.it/post/13491/edna-stvincent-millay-la-mia-candela-brucia-da-duelati>

${ }^{11}$ Abbott's 1929 portrait of Millay is reproduced here: <http://www.npg.si.edu/exhibit/poets/pop-ups/millay.html> 
${ }^{12}$ Abbott's 1930 portrait of Millay is reproduced here:

<http://pariswasawoman.tumblr.com/post/93218020519/demaupin-portraits-by-bereniceabbott-of-the>

${ }^{13}$ In an undated letter (ca. 1930s), Lucie Delarue-Mardrus suggested that Romaine Brooks could paint Millay’s portrait.

${ }^{14}$ For example, Wikipedia uses Van Vechten's 1933 photograph; the cover of Millay at 100 reproduces the 1930 Mishkin portrait, and an Abbott photograph from 1929 appears on the cover of Walker’s Masks Outrageous.

${ }^{15}$ Eisenstaedt's photograph can be found here:

$<$ https://www.google.com/culturalinstitute/asset-viewer/edna-st-vincentmillay/OgH0aUJit0Kr0w?hl=en> 


\section{Works Cited}

Abbott, Berenice. Letter to Edna St. Vincent Millay, February 11, 1929. Box 74, Folder 1, Edna St. Vincent Millay Papers, Manuscript Division, Library of Congress, Washington, D.C.

Armstrong, Isobel. Victorian Poetry: Poetry, Poets and Politics: Poetry, Poetics, Politics. London: Routledge, 1993. Print.

Atkins, Elizabeth. Edna St. Vincent Millay and Her Times. Chicago: University of Chicago Press, 1936. Print.

Berger, John. Ways of Seeing. London: Penguin, 1972. Print.

Breuer, Elizabeth. "Edna St. Vincent Millay: An Intimate Glimpse of a Famous Poet.” Pictorial Review November 1931: 2, 50-57. Print.

Brown, Susan. "The Victorian Poetess.” The Cambridge Companion to Victorian Poetry. Ed. Joseph Bristow. Cambridge: Cambridge University Press, 2000. 180-202. Print.

Cheshire, Jim, et al (Ed.). Tennyson Transformed: Alfred Lord Tennyson and Visual Culture. Aldershot and Burlington: Lund Humphries, 2009. Print.

Collecott, Diana. H.D. and Sapphic Modernism. Cambridge: Cambridge University Press, 1999. Print.

Collins, Joseph. Taking the Literary Pulse: Psychological Studies of Life and Letters. New York: George H. Doran Company, 1924. Print.

Cucinella, Catherine. Poetics of the Body: Edna St. Vincent Millay, Elizabeth Bishop, Marilyn Chin, and Marilyn Hacker. New York and Basingstoke: Palgrave Macmillan, 2010. Print.

Doan, Laura. Fashioning Sapphism: The Origins of a Modern English Lesbian Culture. New York and Chichester: Columbia University Press, 2001. Print.

Duncan, Isadora. My Life (1927). London: Victor Gollancz Ltd, 1996. Print. 
“Edna St. Vincent Millay Reads Her Poems at Literary Institute.” The Christian Science Monitor 6 May 1925, no page numbers. Print.

Elfenbein, Andrew. Byron and the Victorians. Cambridge: Cambridge University Press, 2004. Print.

Epstein, Daniel Mark. What My Lips Have Kissed: The Loves and Love Poems of Edna St. Vincent Millay. New York: Henry Holt and Company, 2001. Print.

Francis, Elizabeth. "From Event to Monument: Modernism, Feminism and Isadora Duncan.” American Studies 35.1 (1994): 25-45. Print.

Furr, Derek. “Listening to Millay.” Journal of Modern Literature 29.2 (Winter 2006): 94110. Print.

Gilbert, Sandra M. and Susan Gubar. No Man's Land: The Place of the Woman Writer in the Twentieth Century, Volume 3: Letters from the Front. New Haven: Yale University Press, 1994. Print.

Halberstam, Judith. Female Masculinity. Durham: Duke University Press, 1998. Print. Hallett, Nicky. Lesbian Lives: Identity and Auto/biography in the Twentieth Century. London: Pluto Press, 1998. Print.

Hickman, Money L. "Views of the Floating World.” MFA Bulletin 76 (1978): 4-33. Print. Hubbard, Stacy Carson. “Love’s “Little Day”: Time and the Sexual Body in Millay’s Sonnets.” Millay at 100: A Critical Reappraisal. Ed. Diane P. Freedman. Carbondale and Edwardsville: Southern Illinois University Press, 1995. 100-116. Print.

Hurd Jr., John. "Poets and Writers Flock to Bowdoin for the Round Table of Literature.” Boston Sunday Globe 10 May 1925. 12. Print.

Kenyon Jones, Christine. “Byron’s Body.” Byron: The Image of the Poet. Ed. Christine Kenyon Jones. Newark: University of Delaware Press, 2008. 99-110. Print. ---. “Fantasy and Transfiguration: Byron and His Portraits.” Byromania: Portraits of the 
Artist in Nineteenth- and Twentieth-Century Culture. Ed. Frances Wilson.

Basingstoke: Macmillan, 1999. 109-136. Print.

Keyser, Catherine. "Edna St. Vincent Millay and the Very Clever Woman in Vanity Fair.”

American Periodicals: A Journal of History, Criticism, and Bibliography 17.1 (2007):

65-96. Print.

Mason, Emma. Women Poets of the Nineteenth Century. Tavistock, Devon: Northcote House Publishers Ltd, 2006. Print.

Milford, Nancy Savage Beauty: The Life of Edna St. Vincent Millay. New York: Random House, 2001. Print.

Millay, Edna St. Vincent [as "Nancy Boyd”]. "Diary of an American Art Student in Paris: Showing How She Succeeded in Going To the Louvre Every Day.” Vanity Fair November 1922, 44. Print.

--- [as “Nancy Boyd”]. “The Greek Dance: — A Chorus of Hate.” Vanity Fair August 1921, 47. Print.

---. Edna St. Vincent Letters. Ed. Allan Ross Macdougall. Camden, Maine: Down East Books, 1952. Print.

Michailidou, Artemis. “Gender, body, and feminine performance: Edna St. Vincent Millay’s impact on Anne Sexton.” Feminist Review 78 (November 2004): 117-140. Print.

Morel, Gaëlle “New York - Paris - New York: The Photographic Modernism of Berenice Abbott (1923-1932).” Berenice Abbott. Ed. Gaëlle Morel. New Haven: Yale University Press, 2012. 10-21. Print.

Munich, Adrienne and Melissa Bradshaw, Eds. Amy Lowell, American Modern. New Brunswick: Rutgers University Press, 2004. Print.

Peterson, Linda H. "Presenting Alice Meynell: The Book, the Photograph, and the Calendar.” Women Writers and the Artifacts of Celebrity in the Long Nineteenth Century. Eds. 
Ann R. Hawkins and Maura Ives. Farnham, Surrey and Burlington, VT: Ashgate, 2012. 169-187. Print.

Prins, Yopie. Victorian Sappho. Princeton: Princeton University Press, 1999. Print.

Reynolds, Margaret, ““I lived for art, I lived for love”: The Woman Poet Sings Sappho’s Last Song.” Victorian Women Poets: A Critical Reader. Ed. Angela Leighton. Oxford: Blackwell, 1996. 275-306. Print.

Saville, Deborah. “Dress and Culture in Greenwich Village.” Twentieth-Century American Fashion. Eds. Linda Welters and Patricia A. Cunningham. Oxford and New York: Berg Publishers, 2005. 33-56. Print.

Smith, Lindsay. The Politics of Focus: Women, Children, and Nineteenth-century Photography. Manchester: Manchester University Press, 1998. Print.

Tchen, John Kuo Wei. Genthe’s Photographs of San Francisco’s Old China Town. New York: Dover Publications, 1984. Print.

Vantine, A. A. and Company. Vantine's: The Oriental Store Catalogue. New York: The Company, 1919. Print.

Walker, Cheryl. “The Female Body as Icon: Edna Millay Wears a Plaid Dress.” Millay at 100 A Critical Reappraisal. Ed. Diane P. Freedman. Carbondale and Edwardsville: Southern Illinois University Press, 1995. 85-99. Print.

Walker, Cheryl. Masks Outrageous and Austere: Culture, Psyche, and Persona in Modern Women Poets. Bloomington and Indianapolis: Indiana University Press, 1991. Print. Weissman, Terri. The Realisms of Berenice Abbott: Documentary Photography and Political Action. Berkley and Los Angeles, California: University of California Press, 2011. Print.

Zellinger, Elissa. “Edna St. Vincent Millay and the Poetess Tradition.” Legacy 29.2 (2012): 240-262. Print. 


\section{IMAGES (also attached as TIFF files)}

\section{Figure 1:}

Arnold Genthe’s Portrait of Edna St. Vincent Millay (from a negative dated 1914)

Library of Congress, Prints \& Photographs Division, Arnold Genthe Collection: Negatives and Transparencies, LC-G432-0755-A

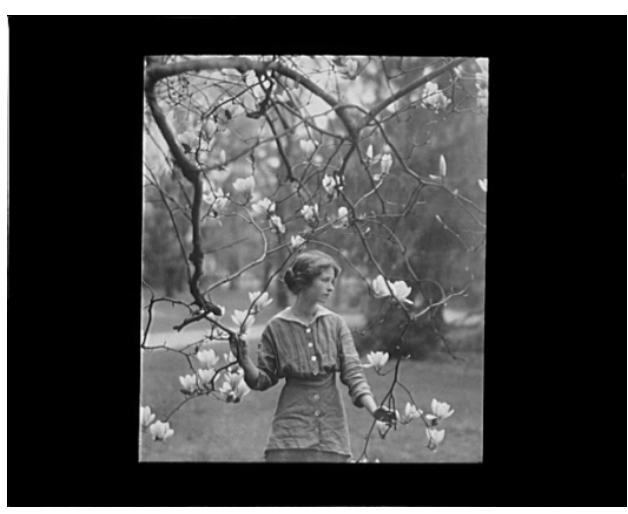




\section{Figure 2:}

Arnold Genthe, ‘Isadora Duncan dancers’

Photographic negative made between 1915 and 1923.

Library of Congress, Prints \& Photographs Division, Arnold Genthe Collection: Negatives and Transparencies, LC-G39-T-0958

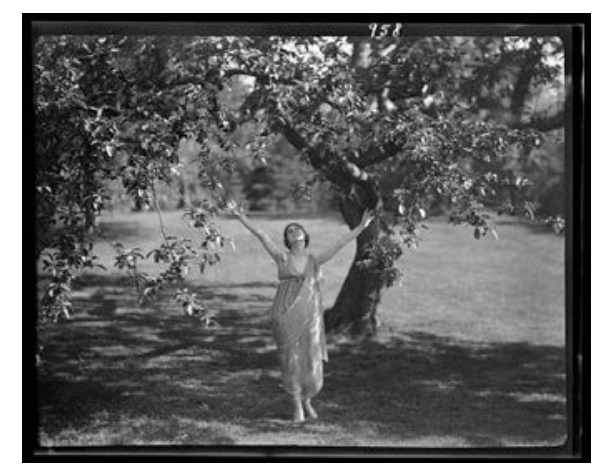




\section{Figure 3:}

Edna St. Vincent Millay wedding album (Croton, New York, 1923)

Box 122, Folder 6, Edna St. Vincent Millay Papers, Manuscript Division, Library of Congress, Washington, D.C.

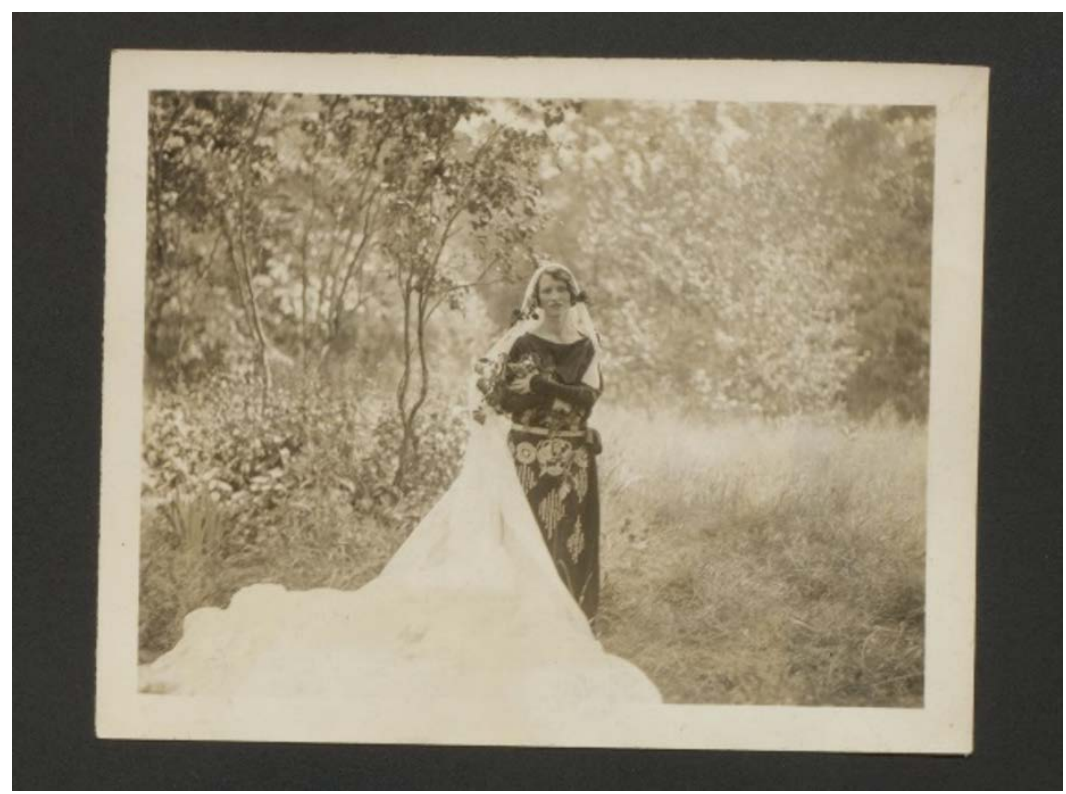




\section{Figure 4:}

Millay as Marchbanks in Candida (Vassar, 1915)

Box 126, Folder 5, Edna St. Vincent Millay Papers, Manuscript Division, Library of Congress, Washington, D.C.

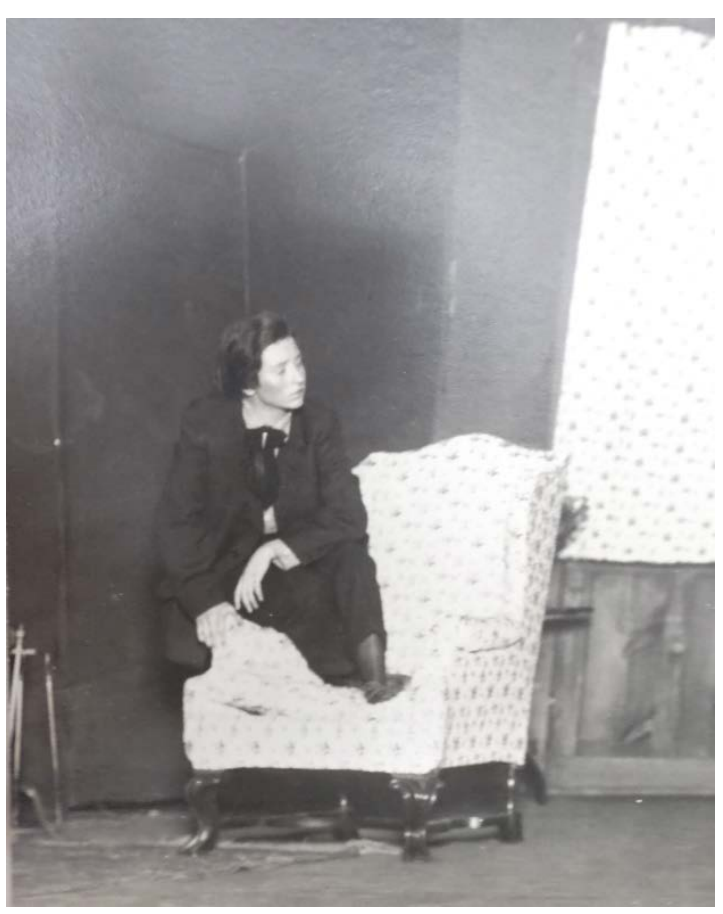




\section{Figure 5:}

Millay in Albanian costume (1921)

Box 125, Folder 7, Edna St. Vincent Millay Papers, Manuscript Division, Library of Congress, Washington, D.C.

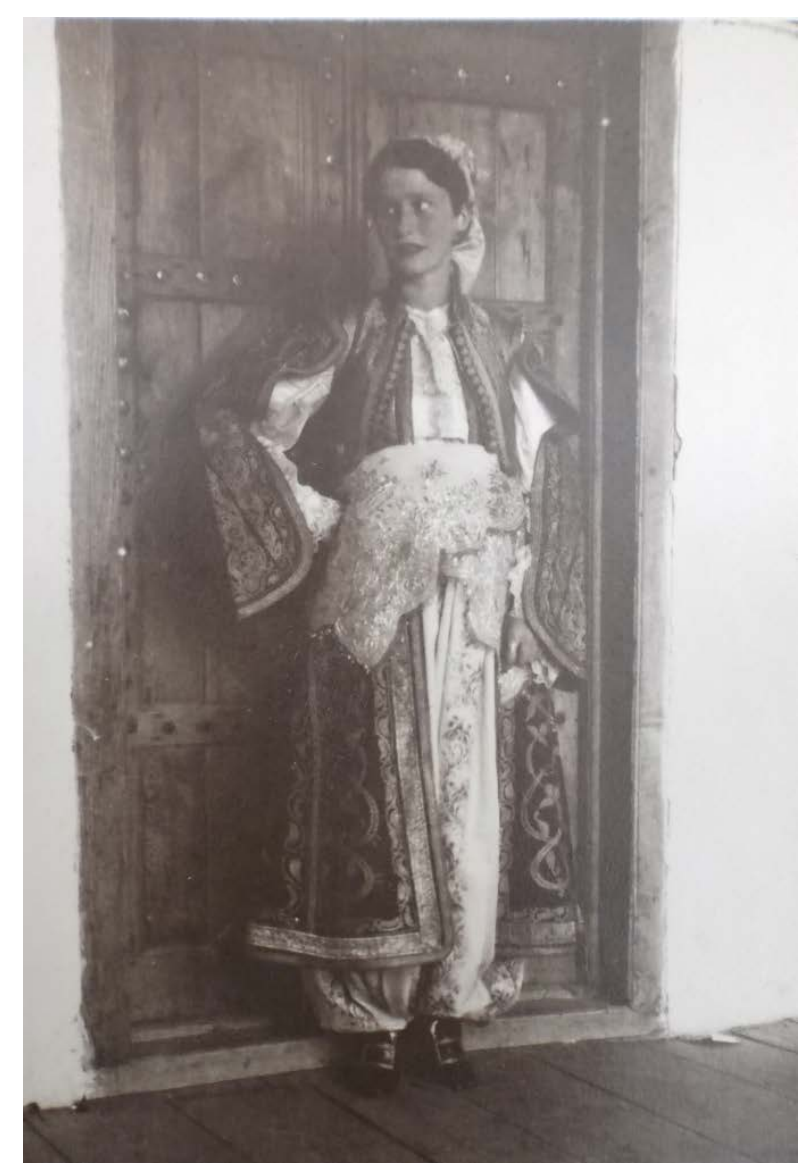




\section{Figure 6:}

Herman Mishkin, Edna St. Vincent Millay (ca. 1927)

Box 24, Folder 8, Edna St. Vincent Millay Papers, Manuscript Division, Library of Congress, Washington, D.C.

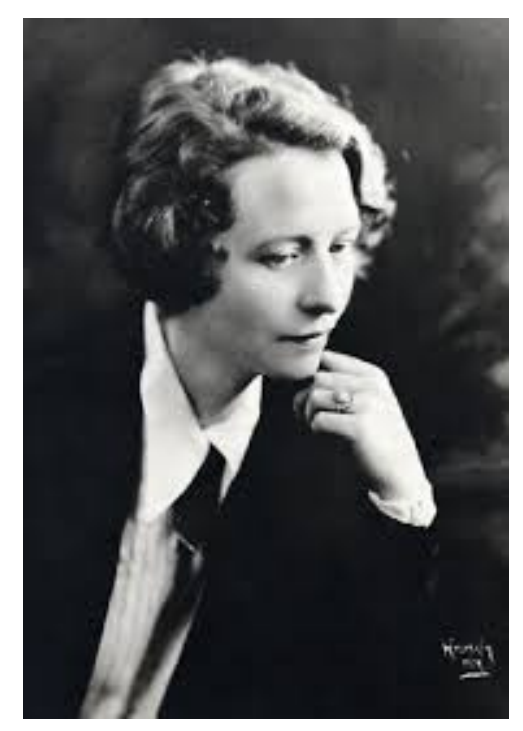




\section{Figure 7:}

Unknown woman, formerly known as Felicia Dorothea Hemans by Unknown artist oil on canvas, circa 1835

(CNational Portrait Gallery, London

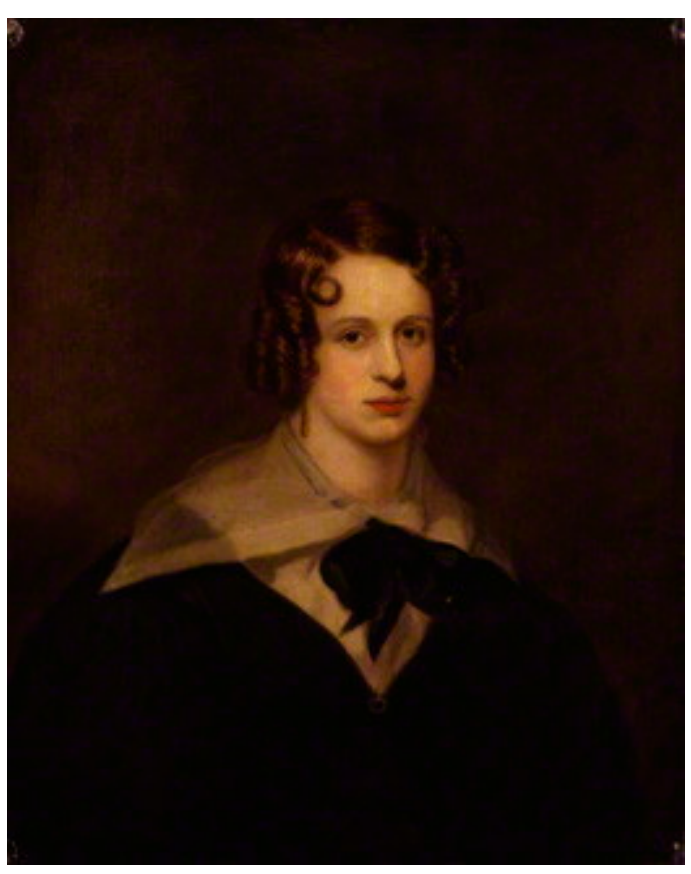




\section{Figure 8:}

Millay photographed for the National Broadcasting Corporation (1942)

Box 124, Folder 7, Edna St. Vincent Millay Papers, Manuscript Division, Library of Congress, Washington, D.C

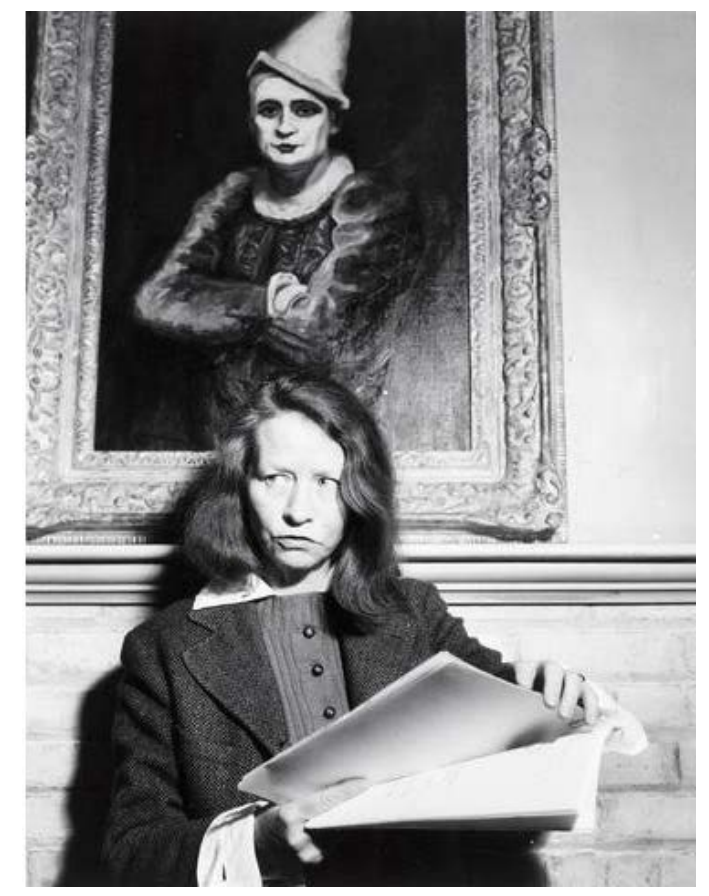




\section{Figure 9:}

E. F. Foley, Millay as clown at Illustrator’s Ball (ca. 1927)

New York World Telegram and Sun Collection, Prints and Photographs Division, Library of Congress, Washington D. C.

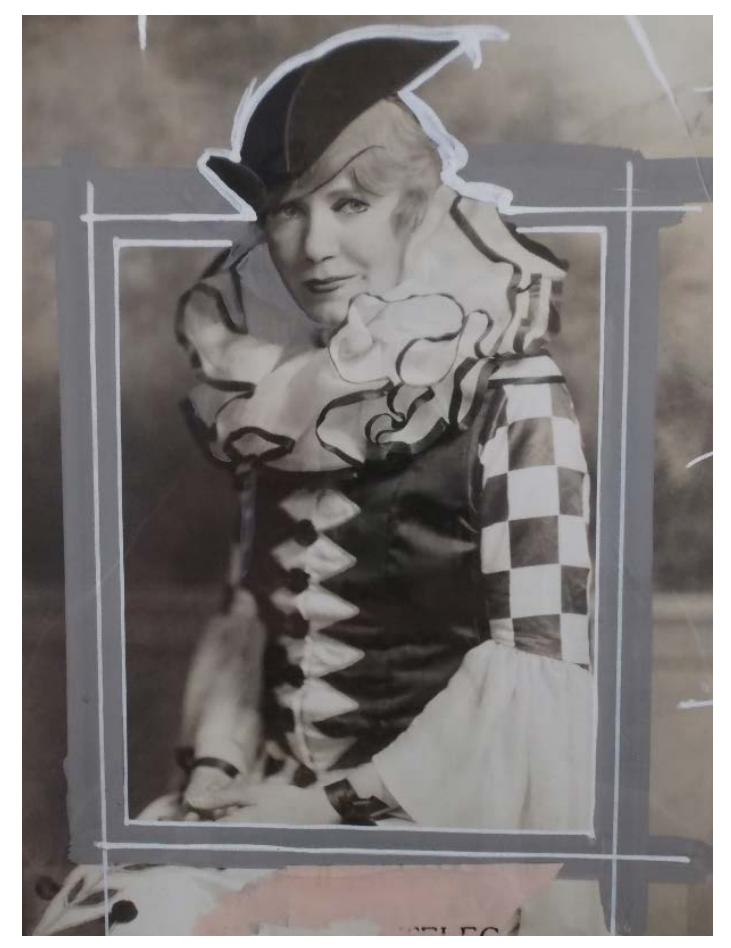

